\title{
PENGARUH FANATISME MAZHAB TERHADAP KEBERHASILAN DAKWAH
}

\author{
Adi Suhara \\ Program Studi Komunikasi dan Penyiaran Islam STAI As-Sunnah Deli Serdang \\ Jl. Medan-Tg. Morawa, Km. 13 Gang Darmo, Desa Bangun Sari, Kab. Deli Serdang
}

\begin{abstract}
Abstrak: Penelitian bertujuan untuk mengetahui pengaruh fanatisme mazhab terhadap keberhasilan dakwah. Hasil penelitian ini adalah fanatisme mazhab yang ditolak oleh Islam adalah bentuk dari pembelaan atau keberpihakkan seseorang terhadap orang lain atau kelompok yang melakukan kebathilan atau kelompok yang berposisi salah yang tidak dibenarkan oleh Islam atau pembelaan atau keberpihakkan seseorang terhadap orang lain atau kelompok yang berposisi benar namun pembelaan tersebut dapat melahirkan hal yang tidak dibenarkan oleh Islam. Sedangkan fanatisme mazhab yang dibolehkan adalah pembelaan atau keberpihakan seseorang terhadap orang lain atau kelompok tanpa menimbulkan kesan yang negatif atau berefek negatif terhadap ummat dan dakwah. Fanatisme Mazhab yang negatif bertentangan dengan Islam dan dapat menghancurkan dakwah Islam dan memecah barisan kaum muslimin. Fanatisme mazhab yang negatif timbul karena ketidakpahaman terhadap sistematika pengambilan hukum Islam dan cara penggunaan dalil-dalil yang ada. Fanatisme mazhab yang negatif dapat memecah ummat dan membuat dakwah tidak efektif dan berhasil disebabkan terpecahnya usaha dakwah dan tidak fokus dan tidak saling tolong menolong dan bekerja sama.
\end{abstract}

Kata Kunci: Pengaruh Fanatisme Madzhab, Keberhasilan Dakwah.

\section{Pendahuluan}

Kekuatan dan kelemehan sebuah kelompok, masyarakat, negara atau ummat terletak pada kesatuan dan persatuan mereka. Perpecahan merupakan awal malapetaka yang membawa kumunduran dan kehancuran.

Walisongo merupakan contoh dan simbol bagi para ulama dan da`i, mereka memiliki teladan yang cukup luar biasa dalam masalah toleransi pendapat dalam menyebarkan Islam di nusantara. Perbedaan dalam metodologi dakwah yang masing-masing gunakan tidaklah menimbulkan perpecahan ummat dan maksud dari ditegakkannya dakwah itu sendiri, persatuan dan kesatuan lebih 
mereka kemukakan dari pada menyibukkan diri pada masalah furu iyah sehingga mereka berhasil dalam menyebarkan Islam di tanah jawa khususnya.

Di antara kisah yang menunjukkan ketoleransian antara pendapat yang terjadi pasca walisongo yaitu kisah yang sangat populer dikalangan Nahdhatul Ulama (NU), bahwa Kiai Hasyim Asy'ari pernah menulis sebuah artikel dalam majalah Suara Nahdhatul Ulama pada tahun 1926, beberapa bulan setelah NU didirikan. Dalam artikel tersebut beliau berpendapat bahwa 'kentongan' bukan 'beduk', sehingga kentongan tidak boleh digunakan untuk menandakan waktu shalat. Namun pendapat ini ditentang oleh Kiai Faqih dari Gersik, beliau berfatwa bahwa kentongang sama seperti beduk sehingga boleh digunakan untuk menandakan waktu shalat telah masuk. ${ }^{1}$

Walaupun mereka berdua berbeda pendapat namun jiwa toleran yang mereka miliki sangat luar biasa, ini terlihat pada beberapa bulan dari perbedaan pendapat tersebut yakni ketika Kiai Hasyim diundang untuk menghadiri perayaan Maulid Nabi di Gresik. Tiga hari sebelum tiba, Kiai Faqih membagikan surat kepada semua masjid dan mushalla untuk menurunkan semua kentongan demi menghormati Kiai Hasyim dan tidak menggunakannya selama Kiai Hasyim di Gersik. $^{2}$ Ini adalah contoh teloran perbedaan pendapat yang begitu Indah dan luar biasa.

Kemudian jika kita lihat masuknya Islam di Indonesia, maka Islam masuk ke negeri ini sudah cukup lama, seyogianya ini mengindikasikaan bahwa muslimin Indonesia telah memiliki pengalaman yang cukup dalam masalah toleransi perbedaan pendapat dalam kalangan sesama, namun hal itu belum sesuai harapan.

Kenyataannya ummat Islam Indonesia yang memiliki kaya corak gerakan dan organisasi Islam, ternyata belum membuat sebahagian mereka dewasa dalam

1. Contoh yang diangkat ini hanya sekedar contoh dalam menunjukkan toleransi perbedaan pendapat, walaupun penulis mengharamkan penggunaan beduk atau kentong untuk menandakan waktu shalat telah masuk.

2. http://www.muktamarnu.com/hikayat-wakil-rais-akbar-dan-kentongan-3-tamat.html. 
menyikapi perbedaan furu`iyah yang bersifat zhanni (debat table), sehingga sebahagian mereka disibukkan dengan masalah-masalah furu`iyah dan lupa dengan asasiyah, bahkan terkadang kurang adanya toleransi sikap membuat shofful muslimin terpecah belah sehingga berimbas kepada pelemahan gerakan dakwah itu sendiri.

Tidakadanya tasamuh atau toleransi sikap dan menghargai pendapat orang lain, memunculkan sikap merasa paling benar dan dapat memicu sikap pembelaan terhadap kelompoknya secara brutal tanpa meneliti perkara yang diperselisihkan secara mendalam, itu semua dapat kita katakan sebagai ta`asub mazhabi (fanatisme mazhab). Yang sudah pasti hal tersebut membuat gerakan dakwah akan terpecah, kekuatan dakwah tidak bersatu padu, tujuan inti dari dakwah tidak akan tercapai karena penghalang bertambah dan problematika ummat secara interen meningkat sehingga usaha untuk menyebarkan Islam terhambat dan terlambat.

Sejarah telah mengajarkan kepada kita bahwa kekuatan dibangun dan bersumber dari dalam, bukan bersumber dari luar. Jika sesama ummat Islam yang satu akidah dan satu referensi Alqur'an dan Assunnah tidak bisa saling bertasamuh maka tidak akan ada kemenangan dan kejayaan, sebagaimana yang dijelaskan dalam Alqur'an surat Ali-‘Imran ayat 103.

Dikarenakan menjaga persatuan ummat, menjaga hati ummat dan menghormati pendapat orang lain demi tujuan utama yaitu menegakkan syari at Islam maka makalah ini akan memaparkan secara sederhana tentang bagaimana pengaruh ta`ashshub mazhabi menghambat gerakan dakwah.

\section{Definisi Fanatisme}

Menurut Kamus Bahasa Indonesia fanatisme bermakna kepercayaan yang terlalu kuat terhadap ajaran agama atau politik dan sebagainya ${ }^{3}$.

Definisi di atas memahamkan bahwa fanatisme hanya berkisar pada kepercayaan atau keyakinan dan tidak berkaitan dengan aksi yang timbul dari konsekuwensi kepercayaan tersebut apabila kepercayaannya dihina atau

3 . Departemen Pendidikan Nasional, Kamus Besar Bahasa Indonesia ( Jakarta: PT Gramedia Pustaka Utama, 2008.), edisi IV, hal. 388 
dilecehkan. Tentu definisi kurang konferhensif jika dibandingkan dengan defenisi fanatisme menurut bahasa arab, oleh karena itu penulis lebih memberatkan definisi fanatisme menurut bahasa arab dari bahasa Indonesia dikarenakan defenisinya lebih akurat atau jami` dan mani`.

Fanatik dalam bahasa arab adalah atta`ashshub. Sedangkan fanatisme adalahal'ashobiyah. Menurut bahasa arab al'ashobiyah atau fanatisme bermakna seseorang yang mengajak orang lain untuk membela atau menolong golongannya dan memihak kepada golongannya, baik golongan tersebut dalam posisi yang melakukan kezhaliman atau dalam posisi yang dizhalimi. Dan fanatik juga berarti saling melindungi dan saling membela. ${ }^{4}$

Dari definisi di atas dapat kita pahami bahwa fanatisme adalan segala hal yang menunjukkan akan makna membantu, membela, menolong, melindungi, dan sejenisnya yang menunjukkan keberpihakkan seseorang kepada suatu kelompok, suku, negara, mazhab atau agama. Baik keberpihakkan tersebut membantu atas kezhaliman, kesalahan, kekeliruan orang yang dianggapnya kelompoknnya atau keberpihakkan tersebut didasarkan kebenaran dan menumpas segala bentuk kezhaliman atau kekeliruan.

Jadi fanatisme sendiri memiliki dua makna yaitu fanatisme negatif yakni membela atau membantu kezaliman dan fanatisme positif yakni membela keadilan dan memberantas kezaliman.

Dalam Islam hal yang dianggap fanatisme adalah fanatisme yang bersifat negatif yaitu segala jenis keberpihakan atau pembelaan seseorang kepada orang lain atau suatu kelompok yang kelompok tersebut dalam posisi yang tidak sesuai dengan ajaran Islam seperti pembelaan terhadap kelompok yang melakukan kezhaliman dan tidak menegakkan keadilan dan sebagainya.

Hal ini telah dijelaskan oleh Rasulullah shallallahu alaihiwasalam tatkala beliau ditanya: apakah termasuk fanatisme seseorang membela golongannya

\footnotetext{
4. Ibnu Al-Manzhur, Lisanul `Arab, cet. I (Beirut : Dar Shoder ), vol. 1, hal. 602.
} 
dalam kebenaran? Rasulullah menjawab: tidak, akan tetapi termasuk fanatisme adalah seseorang yang membela kaumnya dalam kebathilan. ${ }^{5}$

Dari sini dapat kita kembangkan bahwa inti dari makna fanatisme negatif adalah pembelaan terhadap yang tidak dibenarkan oleh Islam seperti kezhaliman. Oleh karena itu segala bentuk fanatisme negatif dilarang oleh Islam karena fanatisme merupakan penyokong atau pembantu agar kebathilan itu tetap terwujud. Dan pada hakikatnya fanatisme terhadap kebathilan adalah sama dengan kebathilan itu sendiri yang harus dilenyapkan dan sudah pasti bertentangan dengan ajaran Islam.

Kemudian fanatisme mencakup segala jenis fanatisme seperti fanatisme keluarga, suku, golongan, organisasi, partai, yayasan, sekolah, agama atau fanatisme mazhab, pembahasan kita adalah fanatisme mazhab.

Jika inti dari fanatisme negatif adalah keberpihakan seseorang terhadap kelompok yang pada posisi yang tidak dibenarkan oleh Islam seperti kebathilan maka fanatisme positif juga dapat mengakibatkan secara tidak langsung mendatangkan hal yang tidak dibenarkan oleh syari at Islam seperti pembelaan terhadap suatu pendapat, mazhab atau golongan yang berakibat memecah persatuan ummat, menyakiti hati orang lain atau menimbulkan al'ashobiyah terhadap kelompok atau mazhabnya sehingga menganggap kelompoknya benar dan yang lain salah, dsb, yang kesemuanya itu dapat digolongkan pada fanatisme negatif karena berdampak negatif terhadap ummat dan dakwah.

Dari penjelasan di atas dapat disimpulkan bahwa fanatisme mencakup tiga bentuk:

1. Pembelaan atau keberpihakkan seseorang terhadap orang lain atau kelompok yang melakukan kebathilan atau kelompok yang berposisi salah yang tidak dibenarkan oleh Islam.

5 . Sunan Abu Daud, no. (5119). 
2. Pembelaan atau keberpihakkan seseorang terhadap orang lain atau kelompok yang berposisi benar namun pembelaan tersebut dapat melahirkan hal yang tidak dibenarkan oleh Islam.

3. Pembelaan atau keberpihakan seseorang terhadap orang lain atau kelompok tanpa menimbulkan kesan yang negatif atau berefek negatif terhadap ummat dan dakwah.

Yang perlu ditegaskan adalah no. 1 dan 2 adalah fanatisme negatif yang dilarang dan yang no. 3 adalah fanatisme yang dibenarkan karena ia merupakan fanatisme positif. Hal itu yang terjadi pada ummat Islam sehingga timbulnya empat mazhab dalam perkembangan fiqih Islam atau Maturidi dan Asy`ari dalam perkembangan akidah Islam sehingga madrasah-madrasah dan golongan-golongan ini tersebar keseluruh dunia Islam tanpa membuat perpecahan terhadap ummat atau berefek negatif terhadap perjalanan dakwah. Namun jika pembelaan terhadap golongan tersebut di atas membuat efek negatif maka itulah yang dikatakan fanatisme negative

\section{Contoh-contoh Fanatisme Mazhab Negatif.}

Di antara problematika ummat dan dakwah yang merusak gerakan dakwah dan menghambat laju dan keberhasilan dakwah adalah Permasalahan ta ashshubiyah mazhabiyah secara khusus. Dalam perjalanan sejarah fiqih Islami masalah ta`ashshubiyah mazhabiyah yang negatif bukan hal yang baru yang terjadi, namun ini merupakan masalah yang sudah kuno yang seyogianya banyaknya contoh-contoh yang telah terjadi dalam sejarah menjadikan ummat Islam memiliki sifat toleran dan menjadikan hal tersebut budaya perbedaan dan menambah kekuatan pemikiran dalam permasalahan fiqih khususnya, namun disayangkan banyak di antara pengikut mazhab belum dapat memahami akan perbedaan tersebut sehingga timbullah ta`ashshub terhadap pendapat yang dipegangnya dikarenakan beberapa asfek.

Jadi apa yang terjadi dewasa ini yaitu isme mazhab diantara dua golongan atau lebih atau diantara pengikut mazhab yang berbeda merupakan hal yang 
lumrah dan biasa karena sejarah juga telah mengantongi beberapa kejadian yang bernuansa negatif tentang ta $a s h s h b$ mazhab, dan diantara bentuk fanatisme yang keluar dari Islam dan berbahaya terhadap lajunya gerakan dakwah adalah sebagai berikut:

Salah seorang yang fanatik kepada Mazhab Syafi`i ditanya tentang hukum makanan yang dijatuhi setetes minuman khamar ? maka ia menjawab: makanan itu diberikan untuk anjing atau orang yang bermazhab Hanafi. Lahaula wala quwwata Illah billah. Bagaimana anjing disamakan dengan orang yang bermazhab hanafi . . . !!!

Sebaliknya salah seorang yang fanatik kepada mazhab Hanafi ditanya tentang hukum pernikahan laki-laki yang bermazhab hanafi dengan wanita yang bermazhab syafi i ? Ia menjawab: tidak boleh, karena wanita tersebut diragukan keimanannya. Hal ini disebabkan keterangan dalam mazhab syafi i yang menjelaskan bahwa tidaklah seseorang dikatakan kafir jika mengatakan 'saya beriman InsyaAllah', dengan niat mengambil keberkahan lafaz (insyaAllah) tersebut. Namun hal ini berbeda dengan pendapat mazhab hanafi yang tidak membolehkan menambahkan lafaz 'insyaAllah' dalam hal keimanan, sehingga orang yang mengatakan lafaz tersebut dianggap meragukan keimanannya dan orang yang meragukan keimanannya tidak termasuk dalam Islam. Oleh karena itu pernikahannya tidak sah.

Bahkan yang lebih aneh lagi, sebahagian orang yang fanatisme dengan mazhab hanafi mengatakan: boleh seorang laki-laki yang bermazhab hanafi menikahi wanita yang bermazhab syafi'i karena diqiyaskan kepada wanita ahli kitab (Kitabiyah), yakni sama hukumnya wanita yang bermazhab syafi’i dengan wanita ahli kitab. ${ }^{6}$

Ini adalah salah satu kasus dari ratusan kasus yang terjadi dalam sejarah akan perbedaan pendapat yang berakhir kepada fanatisme mazhab yang negatif, dan sangat memperihatinkan bagaimana sebahagian ummat Islam disebabkan

6 . Baca: M. Ghazali, Dustur Alwahdah Atsaqofiyah (Damaskus: Darul Kalam 1424 H), cet. 4, hal. 93-94. 
masalah furu iyah dapat mengkafirkan seluruh atau kebanyakan orang yang bermazhab syafi i, bagaimana masalah furu`iyah ini memecahkan persatuan ummat dan bahkan dapat menumpahkan darah antara dua kelompok yang beriman.

Adapun contoh fanatisme yang terjadi dewasa ini seperti sikap yang diambil oleh sebahagian pengikut suatu golongan A yang tidak memberi kesempatan bagi ulama B yang diluar golongannya untuk memberi taushiyah atau khutbah di masjid golongan A, dikarenakan ulama B tersebut membaca bismillah secara jahar ketika memulai membaca surah Alfatihah, walaupun membaca bismilah sebelum Alfatihah merupakan masalah khilafiyah furu iyah, atau karena ulama B tidak memiliki kartu pengkaderan golongan A tersebut, sehingga si B tidak diperbolehkan untuk ceramah di depan golongan A dikarenakan tidak pernah mengikuti tarbiyah atau memiliki kartu golongan A, walaupun si B adalah seorang yang dianggap mumpuni dalam keilmuannya, atau seseorang tidak boleh diperkenankan menjadi dosen di sebuah universitas disebabkan universitas tersebut pengikut mazhab A dan pemateri pengikut mazhab B atau sebaliknya.

Fanatik ini terjadi dan merupakan hal yang sangat aktual dewasa ini. Contoh-contoh di atas merupakan sekilas gambaran dari ratusan gambaran yang menunjukkan sebuah fanatisme negatif yang terjadi di era modern sekarang yang rentan untuk memecah belah shaf ummat Islam dan menghambat pergerakan dakwah.

Contoh-contoh lain yang dapat menyebabkan perpecahan ummat dalam permasalah khilafiyah furu`iyah seperti masalah maulid Nabi, tawassul, tahlilan, isbal, lafaz sayyidi untuk Rasulullah, masalah shalat tarawih 11 atau 23 raka at dsb, yang semua ini merupakan masalah khilafiyah furu iyah yang telah terjadi cukup lama dan bukanlah masalah asasiyah dalam Islam. Namun sebahagian pengikut suatu mazhab atau golongan tidak memiliki kedewasaan dalam menyikapi perbedaan tentu, hal ini penyebab yang menimbulkan perpecahan hati, perpecahan shaf ummat, melemahnya ukhuwah Islamiyah dan dakwah Islam.

\section{Fanatisme Negatif Bertentangan Dengan Islam}


Fanatisme mazhab yang negatif bertentangan dengan Islam dikarenakan efek negatif yang ditimbulkan oleh fanatisme mazhab tersebut. Fanatisme mazhab yang negatif adalah ajaran jahiliyah.

Ada beberapa hal yang membuat fanatisme negatif yang sangat dibenci oleh Islam sehingga fanatisme ini digolongkan ke dalam ajaran jahiliyah. Di antara efek yang ditimbulkan oleh seorang atau golongan yang berfanatisme mazhab adalah menganggap dirinya atau golongannya benar dan yang lain salah, walaupun permasalahan yang diperselisihkan masih dalam kategori zhanniyatud dalalah (debat table) yang berkemungkinan salah satu diantara keduanya benar. Padahal hal ini masih diperkenankan oleh syari’at sendiri dikarenakan tabiat syari at Islam yang memiliki dua komponen penting dalam pensyari`atan ajaranajaran Islam sehingga Islam dapat berselaras terus dengan perubahan zaman, situasi dan kondisi. Dua komponen tersebut adalah teks-teks Alqur'an dan Alhadits yang bersifat Qath iyatud dalalah (teks yang baku maknanya dan hanya mengandung satu makna) dan teks-teks yang bersifat zanniyutud dalalah (debat table, teks yang mengandung lebih dari satu penafsiran).

Dan perlu dipahami bahwa terjadinya perbedaan pendapat di antara ulama masih dalam ruang lingkup teks-teks yang bersifat zhanniyatud dalalah bukan teks-teks yang besifat Qath iyatud dalalah. Jika demikian maka permasalahan perbedaan hanya terjadi di masalah ijtihadiyah yang dua pendapat yang berbeda atau lebih tidaklah memiliki kebenaran 100 persen, salah satu diantara pendapat itu benar, kemungkinan kebenaran dipihak yang berfanatisme terhadap pendapatnya dan mungkin saja kebenaran dipihak lain. Jika hakikatnya seperti ini maka kenapa harus berfanatisme yang menimbulkan dampak yang negatif terhadap ummat dan membuat efek negatif yang sangat berbahaya bagi ummat seperti memecah belah shafful muslimin, menyakiti hati sesama muslim, merasa sok benar, renggangnya atau pecahnya ukhuwah Islamiyah, tidak saling menghormati, dsb.

Dalam hal ini Imam Syathibi menegaskan bahwa memperhatikan akan konsekwensi atau efek suatu perbuatan merupakan hal yang diperhatikan dan 
dimaksud oleh syari`at, apakah perbuatan yang dilakukan tersebut sesuai atau tidak sesuai dengan syari at. Sehingga seorang mujtahid tidak mengeluarkan suatu hukum dari perbuatan seorang mukallaf untuk ia lakukan atau tidak ia lakukan kecuali mujtahid telah menilai efek dari perbuatan tersebut dan diterima secara syari`at, yakni jika perbuatan yang dilakukan/akan dilakukan berefek pada maslahat yang lebih besar maka ia dibenarkan, akan tetapi jika perbuatan yang dilakukan/akan dilakukan berefek kepada mafsadah yang lebih besar maka ia ditolak. $^{7}$

Oleh karena itu, jika kita aplikasikan dengan masalah fanatisme mazhab maka fanatisme mazhab yang dapat menimbulkan efek negatif yang lebih besar dari mashlahatnya maka ia tidak dibenarkan karena mafsadah yang timbul dari negatifisme mazhab lebih besar dari pada mashlahahnya. Di antara mafsadah tersebut sebagaimana disebutkan di atas seperti pecahnya shafful muslimin, renggangnya ukhuwah Islam, timbulnya fanatisme jahiliyah yang dilarang Islam, dsb hal ini merupakan hal yang membuat ummat tidak bersatu sehingga visi terbesar yaitu menegakkan syari`at Islam terbengkalai dan susah tercapai disebabkan fanatisme negatif tersebut.

Fanatisme mazhab yang bersifat negatif bertentangan dengan Alqur`an dan Assunnah dari segi efek yang ditimbulkan dari fanatisme tersebut yaitu fanatisme dapat memecah persatuan dan melemahkan ummat dan dakwah Allah Ta`ala berfirman dalam surah Ali- Imran, ayat 103:

Dan berpeganglah kamu semuanya kepada agama Allah, dan janganlah kamu bercerai berai, dan ingatlah akan nikmat Allah kepadamu ketika kamu dahulu (masa Jahiliyah) bermusuh-musuhan, maka Allah mempersatukan hatimu, lalu menjadilah kamu karena nikmat Allah, orang-orang yang bersaudara; dan kamu telah berada di tepi jurang neraka, lalu Allah menyelamatkan kamu dari padanya. Demikianlah Allah menerangkan ayat-ayat-Nya kepadamu, agar kamu mendapat petunjuk.

\footnotetext{
7 . Baca: Asyathibi , Almuwafaqat (Beirut: Dar Alma`rifah, t.t), vol. 4, hal. 194.
} 
Ayat Ini menegaskan kepada semua ummat Islam bahwa wajib atas ummat untuk menjaga persatuan dan jangan bercerai-berai. Ayat ini juga mengingatkan kita bagaimana perpecahan membuat dua kabilah besar Aus dan Khajraj saling merugi dan tidak ada yang diuntungkan, begitu juga jatuhnya negara-negara Islam seperti negara Islam Andalus dan terbiarkannya negeri Palestina sampai sekarang, itu semua disebabkan perpecahan ummat dan disebabkan fanatisme mazhab atau golongan atau negara.

Allah juga menegaskan dalam surah Al-Anfal, ayat 46:

Dan taatlah kepada Allah dan Rasul-Nya dan janganlah kamu berbantahbantahan, yang menyebabkan kamu menjadi gentar dan hilang kekuatanmu dan bersabarlah. Sesungguhnya Allah beserta orang-orang yang sabar.

Dari dua ayat di atas dapat kita pahami bahwa menjaga persatuan hukummnya wajib, sedangkan perbedaan pendapat adalah sunnatullah dalam lingkungan teks-teks yang bersifat zanniyatud dalalah, oleh karena itu menciptakan budaya tasamuh atau toleransi demi menjaga persatuan adalah wajib hukumnya. Dan di antara penyebab dakwah Islam Indonesia khususnya tidak berkembang secara efektif adalah fanatisme mazhab yang negatif.

\section{Fanatisme Mazhab dan Zhanniyatunnash (Debat Table)}

Alqur'an dan Assunnah merupakan sumber asasi syari at Islam, semua hukum harus berkiblatkan kesumber asasi tersebut. Namun yang harus menjadi perhatian juga bahwa dalil-dalil syari at bukan hanya Alqur'an dan Assunnah, tetapi ada Ijma', Qiyas, Mashlahat Mursalah, Sadda Zarai, Alistihsan dsb (Aladillah Almukhtalaf Fiha) yang semuanya itu diambil dari Ruh Syari'ah dan merupakan dalil sah dalam pengambilan suatu hukum Islam. Namun dalam penerapan dalil-dalil (Aladillah Almukhtalaf Fiha) tersebut selain Alqur'an dan Assunnah, Ijma' dan Alqiyas sebahagian ulama lebih meluaskan penggunaan (Aladillah Almukhtalaf Fiha) tersebut dan sebahagian lagi lebih menyempitkan gerak dalam penggunaan dalil-dalil tersebut yang berakibat adanya perbedaan furu iyah dalam menetapkan hukum pada suatu masalah. 
Ditambah lagi, perbedaan penafsiran yang timbul dari Alqur`an dan Assunnah tersebut, dikarenakan sebahagian ayat dan hadits memiliki beberapa penafsiran, sehingga terjadi lagi perbedaan pendapat dalam masalah furu iyah dan bukan asasiyah. Atau yang disebut dengan teks-teks yang bersifat Zhanniyatud Dalalah dan Zhanniyatunnash. ${ }^{8}$

Oleh karena itu, terbentuklah namanya mazhab yang dikenal dengan mazhab Hanafi, Maliki, Syafi`i, Hambali, Sofiyan Tsauri, Auza`i dsb, hal ini dikarenakan setiap mereka memiliki ijtihad tertentu dalam memahami suatu teks yang bersifat zhanniyah tersebut. Tentu hal ini yang dijustifikasikan oleh syari'at Islam sehingga memberi kemudahan bagi ummat Islam untuk memilih yang mudah dan meninggalkan yang susah.

Orang yang tidak memiliki tsaqafah di atas dan memahami secara baik terjadinya perbedaan ulama atau kemampuan menimbang dalil-dalil syar`i sudah tentu tidak mumpuni atau ia tidak mengetahui kecuali pendapat satu orang atau satu kelompok, inilah yang menyebabkan terjadinya fanatisme negatif dalam bermazhab, inilah yang membuat perpecahan shaf ummat Islam karena memaksakan pendapatnya dan tidak menghargai pendapat orang lain, karena ia hanya melihat disatu lobang sedangkan rumah tersebut memiliki beberapa lobang yang dapat digunakan untuk melihat ke luar.

Imam Syathibi juga pernah menyinggung masalah ini dalam kitabnya yang Agung Almuwafaqat, beliau menegaskan bahwa: membiasakan penuntut ilmu untuk tidak melihat kecuali satu mazhab, barangkali itu dapat membuatnya memiliki rasa menjauh bahkan dapat mengingkari mazhab yang lain selain mazhabnya, hal itu karena ia tidak melihat dalil-dalil mazhab yang lain, sehingga hal ini dapat mewarisinya pada keyakinannya rasa tidak simpatik pada keutamaan ulama-ulama yang seluruh ummat telah bersepakat akan keutaman mereka dan

${ }^{8}$ Baca; M. Mu`az Mushtafa Alkhen, Alqath`I waz Zanni, cet. I (Damaskus: Dar Alkalim Athtayyib, $1428 \mathrm{H})$. 
keterdepanan mereka dalam agama dan keahlian mereka tentang Maqoshid Asyari dan memahami tujuan-tujuan pensyari $\operatorname{atan}^{9}$

Minimnya pengetahuan terhadap perbedaan ulama dan dalil-dalilnya untuk sebahagian orang merupakan faktor terbesar timbulnya fanatisme dalam pendapat atau mazhab, sehingga Syekh Algazali pernah menceritakan pengalaman pribadinya dalam sebuah kitabnya, beliau berkata: saya telah bertemu banyak orang yang berfanatisme dan saya mempelajari kondisi psikologi dan pemikiran mereka sehingga saya menemukan dua kerusakan yang menyerang mereka: yaitu kelemahan keilmuan dan minimnya pengetahuan. Mereka menghafal satu teks dan lupa teks yang lain yang berkaitan atau mereka memahami dalalah/makna perkataan diteks ini dan tidak memahami dalalah di teks yang lain dan mereka menyangka bahwa pemahaman dan pengetahuan mereka adalah seluruh agama. ${ }^{10}$

Dari sini dapat kita pahami kenapa seseorang yang fanatik dalam suatu mazhab lebih memaksakan kehendaknya atau lebih 'ngotot' dan lebih bersifat keras terhadap orang yang tidak sesuai dengan pendapatnya, karena mereka menyangka bahwa pendapat mereka yang benar, pendapat merekalah pendapat yang sah dan pendapat yang lain salah, walaupun masing-masing pendapat berdasarkan dalil yang zhanni dan tidak qath ’i, sehingga timbullah radikalisme dalam perasaan, perbuatan, perkataan dan sikap dan mudah sekali untuk menyesatkan orang lain dan bahkan dapat mengkafirkan orang lain. Hal ini dikarenakan keilmuan mereka yang lemah dan pengetahuan mereka terhadap dalil-dalil syar’i yang ada atau cara ulama beristidlal dan beristinbath tidak mereka pahami secara baik dan benar, sehingga mereka bersikap demikian.

Jadi wajar jika kita melihat realita yang ada pada sebahagian kelompok yang mengatakan kepada orang lain dengan perkataan yang menghina atau meremehkan seperti si pulan bid’ah, si pulan sesat, pulan si asy`ari, si pulan wahhabi' dsb, itu karena masing-masing mereka tidak menghargai pendapat orang lain, budaya menghargai pendapat orang lain dan budaya ukhuwah Islamiyah

\footnotetext{
9 . Almuwafaqat, Asyathibi, penerbit: Dar Alma`rifah-Beirut, vol. 2, hal. 391.

10 . Dustur Alwahdah Atsaqofiyah, hal. 94.
} 
tidak subur dan tertanam dalam kepribadian mereka, sehingga terjadilah perpecahan ummat dan mengakibatkan gerakan dakwah menjadi lambat karena terjadi perpecahan sikap, perpecahan hati dan perpecahan metodologi dalam berdakwah.

\section{Fanatisme Mazhab Menghambat Berhasilnya Dakwah}

Fanatisme mazhab merupakan salah satu penyebab kuat untuk tidak berhasilnya ummat Islam dalam mencapai visi besar mereka yaitu tegaknya syari`at Allah Ta`ala di muka bumi.

Allah Subhanahu wa Ta `ala menegaskan dalam surah Al-Anfal, ayat 46 bahwa kekuatan ummat Islam terletak dalam kuatnya persaudaraan mereka dan tidak berpecah belah, Allah Ta`ala berfirman yang artinya: Dan taatlah kepada Allah dan Rasul-Nya dan janganlah kamu berbantah-bantahan, yang menyebabkan kamu menjadi gentar dan hilang kekuatanmu dan bersabarlah. Sesungguhnya Allah beserta orang-orang yang sabar.

Syekh Abdurrahman Assa'di bahwasanya Allah menjelaskan sesungguhnya bersatunya hati ummat mukmin, keteguhan mereka dan membuang perselisihan diantara mereka adalah kunci kemenangan dari musuh-musuh. Dan jika kamu meneliti akan negara-negara Islam, maka sebab utama kehancuran kekuasaan mereka adalah meninggalkan Islam dan perpecahan yang sangat diharapkan oleh musuh dan menjadikan ini sebagai sarana untuk kehancuran ummat. $^{11}$

Rasulullah shallallahu’alaihi wasallam juga bersabda : yadullah ma`al jama $a h^{12}$, yakni bantuan Allah, pertolongan Allah jika ummat berjama`ah, bersatu dan tidak bercerai berai.

Dari penjelasan di atas dapat kita pahami bahwa titik kelemahan ummat dan titik kelemahan dakwah Islam di antaranya adalah fanatisme mazhab yang membawa pecahnya persaudaraan, pecahnya hati, tersakitinya perasaan orang lain

11 . Andurrahman As-Sa'di, Taisir Karim Arrahmanfi Tafsir Kalam Almannan, cet. I (Muassasah Arrisalah, 1420 H), vol. 1. Hal. 126.

12 . HR. Tirmizi dalam Sunan Attirmizi, no. (2166). 
atau golongan lain, sehingga membuat mereka tidak dapat duduk bersama membicarakan perancangan dakwah yang penuh dengan strategi jitu, akhirnya mereka berdakwah secara terpisah dan terkadang sikap dan keputusan mereka berbenturan dengan mazhab atau golongan lain yang akhirnya usaha dakwah terpecah belah dan tidak fokus, itu semua disebabkan karena hasil dari fanatisme mazhab yang negatif.

Contoh yang sangat memilukan yang aktual yang terjadi di sebahagian tempat di Medan bahwa sebahagian kelompok mazhab membidahkan dan menyesatkan mazhab yang lain dalam masalah zhanniyah, sebahagian kelompok tidak membolehkan ustaz A berceramah atau berkhutbah di masjid golongan B dikarenakan tidak satu aliran atau satu mazhab, bahkan sebahagian kelompok menfonis sesat dan menyesatkan terhadap golongan tertentu dikarenakan berbeda pendapat dan sebagainya.

Hal-hal di atas merupakan segelintir contoh dari banyaknya contoh-contoh yang terjadi dalam masyarakat muslim Indonesia dikarenakan banyaknya aliran dan mazhab atau kelompok. Mereka tidak pernah mendalami bahwa permasalahan khilafiyah dan zhanniyah teks dapat menyebabkan pertumbuhan, efektifitas dan keberhasilan dakwah terhambat dikarenakan fanatisme negatif yang dibenci oleh Allah dan Rasulullah.

Sudah dan sangat sulit untuk bertemu dan bertatap muka untuk membicarakan proyek besar, mendukung terwujudnya masyarakat Islam yang bersyari atkan Islam dalam suatu negara jika kita - ummat Islam - saling tidak menghormati pendapat orang lain atau saling membodohkan dan bahkan menyesatkan satu sama lain.

Oleh karena itu, ummat Islam di Indoensia tidak dapat mewarnai dan tidak dapat mempengaruhi kebijakan ekonomi dan politik walaupun ummat Islam adalah mayoritas dan kita memiliki organisasi-organisasi besar yang berlebelkan Islam. Hal ini tiada lain disebabkan fanatisme mazhab yang memecah belah ummat dan fanatisme itu dikedepankan dari maslahat ummat sehingga dakwah 
ummat Islam di indonesia tidak membuahkan hasil yang maksimal. Wallahu alam bishshawab.

\section{Penutup}

Dari penjelasan di atas dapat kita simpulkan beberapa point berikut ini:

1. Fanatisme mazhab yang ditolak oleh Islam adalah bentuk dari pembelaan atau keberpihakkan seseorang terhadap orang lain atau kelompok yang melakukan kebathilan atau kelompok yang berposisi salah yang tidak dibenarkan oleh Islam atau pembelaan atau keberpihakkan seseorang terhadap orang lain atau kelompok yang berposisi benar namun pembelaan tersebut dapat melahirkan hal yang tidak dibenarkan oleh Islam. Sedangkan fanatisme mazhab yang dibolehkan adalah pembelaan atau keberpihakan seseorang terhadap orang lain atau kelompok tanpa menimbulkan kesan yang negatif atau berefek negatif terhadap ummat dan dakwah.

2. Fanatisme Mazhab yang negatif bertentangan dengan Islam dan dapat menghancurkan dakwah Islam dan memecah barisan kaum muslimin.

3. Fanatisme mazhab yang negatif timbul karena ketidakpahaman terhadap sistematika pengambilan hukum Islam dan cara penggunaan dalil-dalil yang ada.

4. Fanatisme mazhab yang negatif dapat memecah ummat dan membuat dakwah tidak efektif dan berhasil disebabkan terpecahnya usaha dakwah dan tidak fokus dan tidak saling tolong menolong dan bekerja sama. 


\section{Pustaka Acuan}

Alquran Alkarim.

Ghazali, Muhammad. Dustur Alwahdah Atsaqofiyah, cet. IV. Damaskus: Darul Kalam, $1424 \mathrm{H}$.

Asy-Syathibi. Almuwafaqat. Beirut: Dar Alma`rifah, t.t.

M. Mu`az, Mushtafa Alkhen. Alqath I waz Zanni, cet. I. Damaskus: Dar Alkalim Athtayyib, $1428 \mathrm{H}$.

Departemen Pendidikan Nasional. Kamus Bahasa Indonesia. Jakarta: Pusat Bahasa Departemen Pendidikan Pendidikan Nasional, 2008.

Ibnu Almanzhur. Lisanul `Arab, cet. I. Beirut: Dar Shoder, t.t.

Abu Daud. Sunan Abu Daud.

Attirmizi. Sunan Attirmizi.

Abdurrahman As-Sa'di. Taisir Karim Arrahmanfi Tafsir Kalam Almannan, cet. 1. Muassasah Arrisalah, $1420 \mathrm{H}$.

http://www.muktamarnu.com/hikayat-wakil-rais-akbar-dan-kentongan-3tamat.html. 